This is the version of the article accepted for publication in Australian Feminist Law Journal published by Taylor \& Francis: https://www.tandfonline.com/toc/rfem20/current

Accepted version downloaded from SOAS Research Online: http://eprints.soas.ac.uk/24868

\title{
War's Perpetuity: Disabled Bodies of War and the Exoskeleton of Equality
}

\section{Gina Heathcote ${ }^{1}$}

Abstract This paper responds to battlefield technologies that enhance the endurance and capacities of the wearer, known as exoskeletons. Following the argument that exoskeleton technology is set to provide equality for bodies on the battlefield in the near future, I look at how both law and war construct and continually re-deploy a male body as the standard form of materiality within a deeply embedded masculine subjectivity. As such, the male body provides a persistent indicator of what it means to be human. Assistive technologies, such as exoskeletons, work to render female bodies 'closer' to male capabilities in armed conflict situations. At the same time, the maiming of male bodies in conflict can be charted as a persistent outcome of armed conflict that has received scant attention within the study of the gendered effects of armed conflict. War's production of the disabled male body has also led to significant developments with respect to assistive technologies, via the work of, in particular, the US military. I argue that the investment of the US military into the development of exoskeletons, when understood alongside the US military's investment in assistive mobility technologies for returned soldiers, raises questions about the futility of creating technology only to perpetuate the existence of the battlefield. Far from a project built on gender equality goals, investment in exoskeleton technology seemingly underlines the manner in which the male body of war will increasingly be able to return to the battlefield, to be maimed and to be restored in perpetuity. I conclude by arguing exoskeletons should be used to reimagine subjectivity, via debility, with a mindfulness of the material effects and underlying philosophical traces within subjectivity. I argue for a shift in approaching subjectivity via an intersectional and post-human model, rather than a legal subject that perpetuates modernist man, that promotes a thin understanding of gender equality or 
deploys exoskeletons as a tool for the destructive impulses of armed conflict.

${ }^{1}$ Dr Gina Heathcote is a Reader in Gender Studies and International Law at SOAS, University of London and can be contacted at gh21@ soas.ac.uk. The article benefited from the insight of Emily Jones, Mikaela LutterllRowland, Kate Grady and Tyrell Heathcote, as well generous feedback and guidance from Safet Hadzimuhamedovic. All errors remain my own. 
Key words military technology; legal subjectivity; debility; gender equality; exoskeleton

Who would say that spots are alive and help us? Ink, blood, scent . . . what would I do without absurdity and evanescence $?^{2}$

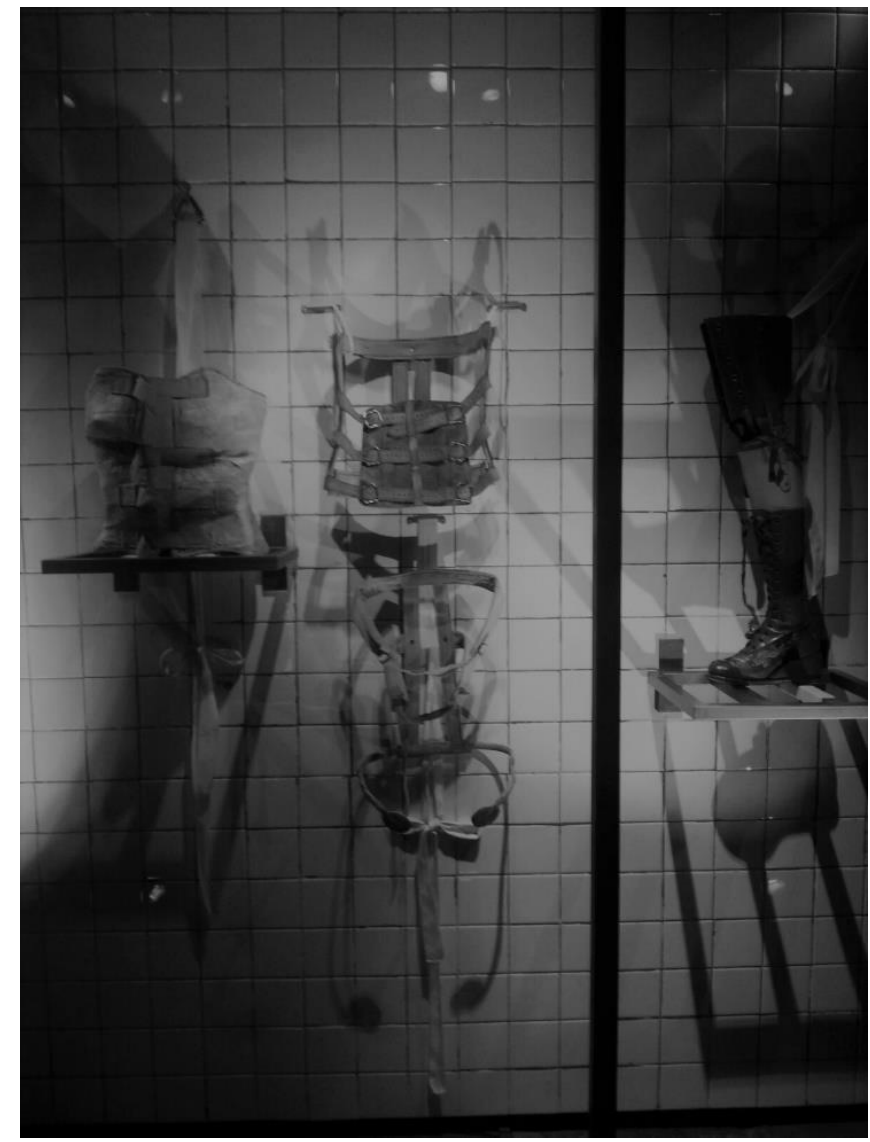

Figure One: Plaster and Leather Braces worn by Frida Kahlo

\section{The Exoskeleton of Equality}

Until July 2016 the British Armed Forces excluded women from roles described as 'close combat roles' on the grounds that their inclusion could impede combat effectiveness. Close combat roles are those that 'are primarily intended and designed with the purpose of requiring individuals on the

\footnotetext{
${ }^{2}$ Attributed to Frida Kahlo, quote recorded on the walls of the Casa Azul, Mexico City. For a slight variation in the translation of this quote, see: Frida Kahlo, The Diary of Frida Kahlo: An Intimate Self-portrait (with Introduction by Carlos Fuentes; essay and commentary by Sarah M. Lowe) (Abrams, 2005). The two images in this article are both photographs in the collection of the author, taken at Casa Azul, June 2017.
} 
ground, to close with and kill the enemy'. ${ }^{3}$ Since July 2016, female soldiers in the UK armed forces could be deployed into these roles, something then Prime Minister, David Cameron - when he announced this in December 2015 - described as a desire to 'finish the job' with respect to gender equality in the UK Armed Forces. ${ }^{4}$ In the US, all combat roles were opened to women in December 2015, with the then US Defense Secretary stating,

There will be no exceptions ... They'll be allowed to drive tanks, fire mortars and lead infantry soldiers into combat. They'll be able to serve as Army Rangers and Green Berets, Navy SEALs, Marine Corps infantry, Air Force parajumpers and everything else that was previously open only to men ... When I became secretary of defense, I made a commitment to building America's force of the future. In the 21 st century that requires drawing strength from the broadest possible pool of talent. This includes women. ${ }^{5}$

Arguments for and against gender restrictions on combat roles in armed forces often focus on questions of efficiency, combat effectiveness and cohesion amongst troops - regardless of whether the speaker is arguing in favour of, or against, gender equality within military roles. ${ }^{6}$ Little discussion emerges of how a need for increased recruitment and retention rates influences armed forces equality measures. Likewise, the impact of changing technologies on the battlefield on recent gender equality strategies, from drones to advances in combat gear, ${ }^{7}$ in both the US and the UK's armed forces, has not received sufficient academic attention. Efficiency arguments and changing technologies present important discussions to be had when armed forces, such as those in the UK and US, embark on

\footnotetext{
${ }^{3}$ Louise Brook-Holland, Women in Combat, Briefing Report Number 7521, House of Commons Library, March 2016, at 3, available online at http://researchbriefings.parliament.uk/ResearchBriefing/Summary/CBP7521\#fullreport (last accessed January 2018)

${ }^{4}$ See: Tim Ross, 'British Army's Women Soldiers go into Combat' December 20 ${ }^{\text {th }} 2015$, The Telegraph, available online at http://www.telegraph.co.uk/news/uknews/defence/12060225/British-Armys-women-soldiersto-go-into-combat.html (last accessed January 2018).

${ }^{5}$ Ashton B. Carter quoted in Matthew Rosenberg and Dave Phillips, 'All Combat Roles Now Open to Women: Defense Secretary Says' The New York Times, Dec $3^{\text {rd }}, 2015$ available online at: https://www.nytimes.com/2015/12/04/us/politics/combat-military-women-ash-carter.html last (accessed January 2018).

${ }^{6}$ For a longer discussion, see Linell Letendre, 'Women Warriors: Why the Robotics Revolution Changes the Combat Equation' (2016) 6(1) Prism: A Journal of the Center for Complex Operations 91 at 93-95.

${ }^{7}$ Lulu Chang, 'The Pentagon is Finally Developing Combat Gear that Fits the Female Form' Digital Trends, $7^{\text {th }}$ March 2016; available online at: https://www.digitaltrends.com/cool-tech/women-combat-gear/ (last accessed January 2018); on drones, see: Louisa Brook-Holland, Overview of Military Drones used by UK Armed Forces, Briefing Paper 06493, House of Commons Library, $8^{\text {th }}$ October 2015, available online at: http://researchbriefings.files.parliament.uk/documents/SN06493/SN06493.pdf (last accessed January 2018).
} 
strategies of gender equality. Embedded within these broader debates are a series of civilising motifs often mobilised via gender equality moves. The civilising impulse of Western military equality reforms, also associated with inclusion policies with regard to lesbian, gay, bisexual, trans and intersex (LGBTI) soldiers, remains insufficiently explored: as if the tantalising lure of technology helps us forget how powerful nations have colonial histories of deploying women's rights and technologies into foreign states to reinforce their own power and centrality to modernist histories. Mindful of the latter, this article considers the perpetuation of the soldier as the archetype citizen of the nation via the US and UK's gender equality projects to explore how both gender equality and new technologies are set to re-assert rather than dismantle enlightenment modes of subjectivity cast on the soldier/citizen.

The article challenges preoccupations with gender equality (and/or technology) that fail to address subjectivity as the underlying structural component of law that is reasserted via gender reforms. I argue that there has been insufficient response to feminist challenges to enlightenment man's persistent presence in Western modes of life and law, and that an understanding of alternative conceptions of subjectivity requires attention to the interconnectedness of humans with matter, nonhumans and technologies. To explore this argument, I begin by introducing the gender equality arguments being adopted by the UK and US militaries to enhance combat effectiveness ${ }^{8}$ and soldiering retention rates, that rest on imagining a female body as the same, or at least capable of being 'as good as', a male body. I articulate a need for a structural feminism that interrogates, and reimagines, the legal/ political assumptions embedded within understandings of subjectivity. I understand subjectivity as the conceptualisation of legal and human subjects that has powerful real world effects in terms of inclusions and exclusions, as well violence, harm and discriminatory impact. I examine subjectivity mindful of its material effects on bodies, as well as discursive violences. In examining the material effects, I consider how the combat and battle readiness of bodies also produces damaged and debilitated bodies that must return from war to be re-made (potentially)

\footnotetext{
${ }^{8}$ For a sustained discussion, see Megan MacKenzie, Beyond the Band of Brothers: The US Military and the Myth that Women Can't Fight (Cambridge University Press 2015).
} 
through assistive and medical technologies. With exoskeletons and the maimed bodies of war side by side it seems not too far off when the same technology that enhances troops on the battlefield will also be used to return the damaged bodies of war to the battlefield. As such, more so than 'killer robots', the perpetual soldier might be the archetype citizen of the future.

In this article, instead of fixating on the bodies maimed and built for warfare, I consider what other purposes assistive technologies might be mobilised for and how the debilitated body might be used to re-imagine legal subjectivity, as embodied and enmeshed in non-human life and structures. I work to claim the lived experience of those outside of (the imaginary existence of) compulsory ablebodiedness ${ }^{10}$ as the starting point for feminist discussions on subjectivity, rather than to render those who already, always encounter technology as a means for survival as abject. The conceptual and the material meanings of subjectivity must thus be spoken and seen together: technology and matter, human and non-human, as spaces of fusion rather than distinction. Exoskeletons might be better regarded as drawing out the complex, fluidity of subjectivity in relation with non-human forms away from the battlefield. I argue that post-Anthropocene arguments for subjectivity that engage interspecies dependencies, human and matter dependencies and the changing meaning of subjectivity constructed through our interface with technology offer a mechanism for feminist scholarship to depart from the perpetuation of male legal subjectivity that past gender law reforms have often reasserted. Subjectivity read in this manner places humans as tiny flecks within a giant prism that might be viewed from multiple stand points and with different illuminations possible. Those tiny flecks are embedded and connected to the prism; part of the prism rather than singular moments of independent life. I conclude by arguing for the presence and visibility of debilitated bodies as a mechanism to trace and embark on concrete political action, to make real the abstraction of posthuman feminisms, and to disrupt modernist man's pervasive grip on the structures of Western political and legal thought.

\footnotetext{
${ }^{9}$ See further, Gina Heathcote, 'Law, UFOs and UAVs: Feminist Encounters with the Laws of Armed Conflict' in Paul Barbie and Dale Stephens (eds), Imagining Law: Essays in Conversation with Judith Gardam, (University of Adelaide Press 2017) 153.

${ }^{10}$ I draw the term compulsory ablebodiedness from Kay Inckle, 'Debilitating Times: compulsory ablebodiedness and white privilege in theory and practice' (2015) 111 Feminist Review 40.
} 


\section{From Exoskeletons of Equality to Interspecies Dependencies}

Before progressing the argument above, I will elaborate the claim made by Letendre that 'robotics will change the equation of women in combat', ${ }^{11}$ such that:

[n]ot only will robotic technology undermine the standard arguments against women in combat, but full gender integration across all combat roles will maximize American employment of autonomous systems and corresponding combat effectiveness. ${ }^{12}$

Letendre reviews the state of gender equality measures within the US armed forces and the role current and upcoming developments in robotics will play in future of combat effectiveness for US forces. Letendre's central argument stems from a series of assumptions about what gender equality is and its value for combat effectiveness. In her discussion of the range of exoskeleton technologies that exist or are in design and testing phases, Letendre provides a history of female advancement and inclusion in the US military that serves to underpin her argument that ' $[\mathrm{t}]$ he combination of roboticenabled enhancements of a soldier's physical capabilities with lighter combat gear and robotic mules will quickly level the physical capability gap between men and women'. ${ }^{13}$ The obvious claim that men will also gain enhanced performances via the same technology is dismissed by Letendre via a return to gender differences, arguing commanders increasingly 'seek out diverse teams especially in the area of robotics because such teams approach issues differently and find more effective and creative solutions to problems'. ${ }^{14}$ Letendre gives as an example the experience of the Israeli Defence Force, where it was

determined that their female soldiers possessed better focus and attention to detail attributes necessary when viewing a multitude of sensors and employing robotic systems in ground combat. Additionally, IDF leadership found women displayed more selfrestraint and deliberation before employment of weapons from the UGV, a skill set much

\footnotetext{
${ }^{11}$ Letendre above note 6.

12 As above.

13 As above at 98 .

14 As above at 99.
} 
in demand during a conflict where collateral damage or killing of non-combatants was heavily scrutinized. ${ }^{15}$

The quick shift away from gender equality arguments to the assumed combat effectiveness gains also returns to a model of gendered subjectivity: where the 'ordinary' (male) soldier presents specific skills that are seemingly hard-wired into his personality and that the female soldier might complement via her alternative skill set. As such, while the gender equality arguments foreground a liberal feminist preoccupation with a formal equality that accepts male-derived subjectivity as the standard form, the women-as-different argument foregrounds a cultural feminist model that leaves intact the standard form and presents woman as the eternal other. Both models articulate gender as static and binary, and do little to dislodge legal subjectivity as a foundational gender arrangement in Western political and legal histories.

Although Letendre's assumptions with regard to gender equality, combat effectiveness and gender as difference would benefit from further unpicking, my focus is to look underneath the liberal feminist and military effectiveness components of Letendre's work to think about the structures of law unacknowledged and yet central to these claims. The foundational legal structure that I therefore analyse throughout this paper is legal subjectivity. Feminist legal scholarship has long challenged the sexed and gendered body that legal subjectivity both renders visible and invisible within law and the ingrained consequences for women's lives. ${ }^{16}$ However, alternative forms of subjectivity offered within feminist legal discourse have struggled with issues of essentialism and the reification of a binary between feminine and masculine stereotypes. Taking inspiration from contemporary theorising on feminist posthumanism, instead of seeking to fix an alternative subjectivity in law, I explore what it means to take seriously the notion that subjectivity - as a motif of humanness - might be best understood as embedded in relationships with non-human actors, technology and matter. As such, I

\footnotetext{
15 As above; also see John Sayle, 'Review of Women in Close Combat Roles: an Analysis' UK Defence Journal, $21^{\text {st }}$ November, 2014 available online at: https://ukdefencejournal.org.uk/review-women-close-combatroles-analysis/ (last accessed January 2018).

${ }^{16}$ Susan James and Stephanie Palmer (eds) Visible Women: Essays on Feminist Legal Theory and Political Philosophy (Bloomsbury 2002).
} 
assume humanness as existing in relationship with matter and non-human animals, yet also hardwired to technology in a manner that might allow us to simultaneously reject the technologies of warfare that veer towards the perpetual soldier through the use of robotics. This enables a theorising of the posthuman as a mechanism beyond the tropes of modernist man.

To make this argument it is useful to review existing feminist legal scholarship on legal subjectivities and the sexed and gendered bodies enacted at law, as well as contemporary gender theories that examine the posthuman as an understanding of humanness as a condition embedded in relationships with matter, technology and the non-human. The first set of scholarship, drawing on Naffine, ${ }^{17}$ questions the foundational claims of liberal legal systems, such as the US and the UK, and their inscription of a gendered and sexed body as both precondition to enlightenment man and as product of his continued operation as motif for political and philosophical discourse. ${ }^{18}$ However, within feminist legal writing on international law it is increasingly clear that the practical solution that permits an embedding of this type of structural change within legal arrangements is not self-evident. Feminist approaches and influence on the development of international law in the late twentieth and early twenty-first century has seen paralysing debates between strategies to re-shape global legal structures and strategies to resist those same structures. ${ }^{19}$ Ultimately neither resistance nor compliance seems a solution if the structural bias of the international legal order remains outside of feminist philosophical, political and legal interventions. ${ }^{20}$ As such, I turn to a second set of feminist scholarship that challenges humanism, modernism and male versions of subjectivity and asks scholars to remember "that the pronoun "we" includes not only humans but also all life on the planet. "We" refers not just to

\footnotetext{
${ }^{17}$ Ngaire Naffine, 'The Body Bag' in Ngaire Naffine and Margaret Owens (eds) Sexing the Subjects of Law (LBC 1997) 79.; also see A. Grear, 'Anthropocene, Capitalocene, Chthulucene': Re-encountering environmental law and its 'subject' with Haraway and New Materialism' in Louis Kotze (ed) Environmental Law and Governance for the Anthropocene (Hart Publishing, 2017) 77.

${ }^{18}$ For an excellent introduction, see Rosemary Hunter, 'Contesting the Dominant Paradigm: Feminist Critiques of Liberal Legalism' in Margaret Davies and Vanessa Munro (eds) The Ashgate Research Companion to Feminist Legal Theory (Routledge 2013) 13..

${ }^{19}$ See further: Sari Kouvo and Zoe Pearson, Feminist Perspectives on Contemporary International Law: Between Resistance to Compliance, (Hart Publishing 2011).

${ }^{20}$ See further: Yoriko Otomo, 'Searching for Virtue in International Law', in Sari Kouvo and Zoe Pearson (eds) Feminist Perspectives on Contemporary International Law: Between Resistance and Compliance? (Hart Publishing 2011) 33.
} 
us but also to everything else. This loss, the price of modernity, may be our undoing' ${ }^{21}$ At the same time, the exoskeleton of equality demonstrates a need not only to see the interspecies and environmental necessities of human existence but also to better engage with how technology already, and always has, re-configured notions of being alive and thus subjectivity.

With a mindfulness of the positioning of intersectionality, in particular via theories of debility and postcoloniality within gender research, I also understand gender as a power structure that does not work in isolation but which is embedded in colonial histories and the tangled vectors of power across gender, race, sexuality and able-bodiedness, in particular. Intersectionality, originating in US critical race feminisms and travelling globally via a range of feminist dialogues, asks feminist and gender theories to be mindful of how gender discrimination and harm is experienced differently when gender intersects with other power relations and spaces of privilege. A considerable amount of work on intersectionality centres on the intersection of race and gender and/or gender and sexuality, less on gender and able-bodiedness. ${ }^{22}$ In an important contribution, Erevelles articulates a need for a 'transnational feminist disability studies perspective' to 'map the continuities between racism, sexism and ableism'. ${ }^{23}$ Erevelles gives recognition to the disability generated by the 'war on terror' in Afghanistan and Iraq to recognise the 'impact of disability in the Third World'. ${ }^{24}$ I argue that the effects of debility within Western states, in this case, the UK and the US must also be centred in feminist re-thinking of subjectivity. ${ }^{25}$

The project of seeing subjectivity differently to the modernist vision of the unencumbered individual of enlightenment then becomes a journey only partially realised through attention to the usual feminist

\footnotetext{
${ }^{21}$ Shelley Wright, Our Ice is Vanishing/Sikuvut Nunguliqtuq (McGill-Queens University Press 2014) 10.

${ }^{22}$ See, importantly, Sadie Wearing, Yasmin Gunaratnam and Irene Gedalof, 'Special Issue on Frailty and Debility' (2015) 111 Feminist Review; Inckle above note 9.

${ }^{23}$ Nirmala Erevelles, 'The Color of Violence: Reflecting in Gender, Race and Disability in Wartime' in Kim Q. Hall (ed) Feminist Disability Studies (Indiana University Press 2011) 117 at 118.

${ }^{24}$ As above.

${ }^{25}$ Also see David Connor, Beth Ferri and Subini Annamma, Disability Studies and Critical Race Theory in Education (Teachers College Press 2016); Robert McRuer, Crip Theory: Cultural Signs of Queerness and Disability (New York University Press 2006); Jasbir Puar, 'Prognosis Time: Towards a Geopolitics of affect, debility and capacity' (2009) 19 Women and Performance: A Journal of Feminist Theory 161.
} 
legal stories of engaging the personal as political and other alternative legal modes in contemporary feminist legal theorising. I am interested, thus, in what alternative structures subjectivity might commence from, with a mindfulness to dislodge the notion of the anthropocentric, male subject and the raced, heteronormative and imperialist dimensions of his existence while also attending to hopefully disrupting - the material and lived effects for those that are less able to emulate the imagined subjectivity of liberal political arrangements. This must shift beyond 'adding on' those cast as 'Other' via a reconfiguration of subjectivity. Matter, non-humans and technology as elements of human existence, both as motif for conceptualisation and marker of lived experience, present the shape and contours of how subjectivity might be reimagined.

Braidotti adds the connection between humans and the environment while emphasising the embedded materiality of conditions and the dynamism of subjectivity. ${ }^{26}$ For Braidotti,

This is also rendered in terms of a general becoming-minority or becoming-nomad or becoming-molecular/women/animal. The minority is the dynamic or intensive principle of change in nomadic theory, whereas the heart of the (phallogocentric) Majority is dead. Insofar as man represents the majority, there is no creative or affirmative "becoming man": the dominant subject is stuck with the burden of self-perpetuating Being and the flat repetition of existing patterns. ${ }^{27}$

In order to disrupt the self-perpetuation of modern man in legal reform, as gender equality moves demonstrate so effectively, I follow Braidotti in taking seriously the relationship between human, nonhuman, matter and technology as in a constant state of flux; so that environment is subject, animal is subject, technology is subject, and humanness is interlocked within these subjectivities.

In seeing environment/ nature / matter as entwined in subjectivity there is a necessity to reject the culture/nature dualism and the notion that humanness is distinct from other systems of life on planet earth. Wright reflects on her lessons learned in the Arctic:

\footnotetext{
${ }^{26}$ Rosi Braidotti, The Posthuman (Polity Press 2013)

${ }^{27}$ Rosi Braidotti, Nomadic Theory (Columbia University Press 2011) 29.
} 
... [w]hen we do think of "Nature," either it might be to see "it" as an inert body "out there" that can be killed, mined, or clear-cut for profit or amusement, or it might be to see our Earth as a suffering victim of human rapacity that needs to be protected or saved. Indeed, the two perspectives are mirror opposites of each other. Those of us who do not live on the land or interact with our fellow creatures in a variety of ways may romanticise "Nature," forgetting that humans are inextricably connected to the chain of life on this planet. ${ }^{28}$

To accept these approaches to subjectivity it seems necessary to recall how and why feminist legal writers have challenged the construction of legal sovereignty as sexed and gendered, but also how a gap emerges in the attempts to use this knowledge as a transformative agenda. Naffine's classic study of criminal law linked the sexing of the subject of law to Western philosophical traditions, in particular Kant, to argue for the body of the legal person as at once rendered irrelevant to law in the mind/body dualism and yet also, always, inscribed as a male body enclosed, sovereign, impenetrable and unencumbered. ${ }^{29}$ Naffine builds on Olsen's earlier work on the gendered construction of liberal dualisms, as well as work on the gendering of the public and private in law, to demonstrate how the sexing of the subject of law works differently to law's gendered effects through the scripting of a subject that is always assumed to be sexed male, and that sex is inscribed as a given, rather than a constructed category.

The sexed subject of law re-emerges in contemporary gender equality moves pursued by Western militaries such as the US and the UK, where the body of the soldier and the legal subject work from an understanding of a norm that women's experience, participation and protection must be added on to existing categorisations. While the male body provides a persistent indicator of what it means to be human in liberal democracies, contemporary innovations, such as exoskeletons, work to renderfemale bodies 'closer' to male capabilities in armed conflict situations, in particular through the increased strength and endurance associated with exoskeleton technologies. As such, exoskeletons re-inscribe modernist and humanist accounts of subjectivity that are gendered in the assumptions they mark out

\footnotetext{
${ }^{28}$ Above note 21 at 9 .

${ }^{29}$ Ngaire Naffine, 'The Body Bag' in Naffine and Owens (eds) Sexing the Subject of Law (LBC 1997) 79.
} 
as definitive of humanness and in the effects they mark on actual bodies. Gender equality provisions, such as the participation provisions found in the Security Council's women, peace and security agenda assume the actors within decision-making bodies to be male and create mechanisms for consulting with women and, sometimes, to include women. Gender training initiatives within US and UK military structures add on information regarding the consequences of sexual exploitation and abuse (to discipline misbehaving peacekeepers) and of sexual violence (to save foreign women) while ignoring how gender functions and produces subjects and effects within the military itself. In addition, gender focal points and gender advisors are appointed as adjuncts to UN missions and military contingents abroad so as to add someone to provide a gender perspective, working on the assumption that the gender beliefs and performances of those already on the mission do not require scrutiny, reflection or engagement. The male military actor is thus assumed to replicate a humanist norm which is unquestioned and ungendered in liberal feminism's performance of both sex and gender.

To think about how the sexed subject is reconfigured within these legal and military manoeuvres there is a need to consider gender as intersectional - with other power structures and thus the perpetuation of intersectional privilege - as well as from a postcolonial lens. Such a view recalls and re-affirms the historical role of gendered law reform as a civilising move that both marks the powerful state as civilised through the rights and recognition afforded to women and marks the vulnerable state as uncivilised for not protecting women or affording women rights. Taking on board both intersectional and postcolonial thinking requires a gender and feminist theory that is different to the focus on rights, on equality or on difference. This is in contrast to the sexed legal subject who epitomises modern man and who, through whichever gender reform, recasts his privilege and subject status to the detriment of non-male, non-white lives.

Viewed from a critique of subjectivity, the use of assistive technologies by militaries pushes feminist and gender theories to shift beyond the critique of the modern man of liberal enlightenment to conceptualise, or take seriously, existing approaches to subjectivity outside of humanism and individualism. This should not, however, involve a jettisoning of the centrality of intersectionality and 
postcolonial insight to contemporary feminist and gender theories. The development of exoskeletons and other assistive technologies by the US military (amongst others) highlights gender equality as a project of 'making' the female subject like male bodies. ${ }^{30}$ At the same time, with appreciation of postcolonial histories, and postcolonial feminist histories in particular, it is important to draw additional attention to how gender equality in Western states and colonial powers has always been used as a tool to mark the civilised and the uncivilised. ${ }^{31}$ Technology and gender equality in relation to global power relations that play out concretely on specific gendered bodies then draws my argument towards a larger scale reimagining of subjectivity than a simple assertion of the gendered and sexed subject of law would permit: challenging compulsory ablebodiedness, I argue, places new mechanisms for exploring the meaning of subjectivity in a post-Anthropocene era that sees matter, non-humans, humans and technology as entwined and relational.

The interconnectedness of humans, non-humans, matter and technology might be imagined via the example of the oil rig in the oceans. Clearly built by humans, the technologies of space and movement on the oil rig impact on the very possibility of human endeavours on a platform located far out at sea. Human interactions on the oil rig are conditioned by its isolation and its design. However, the oceans, the atmosphere and the absence of land also make life on the oil rig something that shapes and changes those who live there. Over time the ocean and the rig re-build the environment, the waves move the rig in time with earthly rhythms, sea life attaches to the structures, food and bodies are imbued with salt, microcosms integrate with bodies and metals, the materials extracted from the earth produce fire hazards, storms and motion change the way humans on the rig move and interact: in essence rig, humans, non-humans and matter create a universe of dependencies and interactions. Rather than an exceptional space, the oil rig might be understood as template of life on earth where the Anthropocene era has evolved a complex interplay of matter, humans, non-humans and technology interfaces that are embedded in the existences and legacies of each other, such that these

\footnotetext{
${ }^{30}$ See Jennifer C. James, 'Gwendolyn Brooks, World War II, and the Politics of Rehabilitation' in Kim Q. Hall (ed) Feminist Disability Studies (Indiana University Press: 2011) 136.

${ }^{31}$ See Vanja Hamzić, 'International Law as Violence: competing absences of the other' in Dianne Otto (ed) Queering International Law (Routledge: 2017) 77.
} 
are not others but webs of meaning, action, life and inaction. The study of obsolete oil rigs shows further how human-made objects impact and respond to the matter and life around them. ${ }^{32}$

Drawing on post-humanist accounts of the interrelatedness of humans to matter, non-humans and technology thus offers a re-imagining of sovereignty that dislodges modernist man's understanding of himself to reconsider the structures of our thinking about the conditions of living on earth while also acknowledging the impact of human inventions/technology as an organic engagement with matter and species. The investment of military technologies and policy into assistive technologies and gender equality for future soldiers, in contrast, re-asserts modern man's subjectivity as template, nature as other and technology as civilising force: all reproducing the colonial, imperial, raced and gendered desires that have always been embedded in liberal enlightenment.

\section{Soldier as arch-citizen}

Prior to thinking about how contemporary configurations of subjectivity might assert new challenges when approaching law, in this section I use military behaviours to examine the persistence of modern man as an organising principle in Western liberal democracies; specifically, the US and the UK. Reviewing gender equality strategies within military structures is a good means to measure the impact of feminist theorising in the late twentieth and early twenty first centuries on conceptualisations of citizenship and belonging. I complement this discussion with a consideration of the maiming of male bodies on the battlefield: despite a shift away from the use of ground forces in foreign military engagements, the US and UK have significant numbers of returned soldiers with physical and mental disabilities that are often under-discussed within legal scholarship. This site of gendered harm ignites a different need for assistive technologies, to repair the returned soldier and offer him or her mobility again, if required. Mental health services for returned soldiers are, however, often less well-resourced

\footnotetext{
${ }^{32}$ Ashley Fowler, Peter Macreadie and David Booth, 'The Beauty of Obsolete Oil Rigs' (2015) 36(5) Australasian Science 28
} 
or utilised by service personnel..$^{33}$ The section closes with a shift away from examining the gender dynamics of these effects to centre debility as a means to re-conceive of legal subjectivities.

2.1 Female soldiers - review of advances of gender equality strategies in Western militaries as reaffirming male subjectivities

Gender equality initiatives within Western military structures represent an important post-millennium development. A key driver of gender equality initiatives has been the Security Council's requirement, under resolution 1960, for the creation of National Action Plans (NAP) from all states to communicate the operationalisation of the Council's women, peace and security agenda. ${ }^{34}$ At the time of writing, sixty-six states have produced NAPs on women, peace and security. The US's second NAP was published in 2016, while the UK's third NAP was released in 2013: the latter was described by the Women's International League for Peace and Freedom as the most specific based on their content analysis. ${ }^{35}$ In this section, I review the role of gender equality measures within armed forces across the NAPs of the UK and the US. This is followed by a discussion of additional key gender equality strategies which include the development of pre-deployment training for troops and the development of all-female teams within peacekeeping and armed conflict scenarios. Throughout it becomes apparent, perhaps with the exception of the short-lived Swedish 'GenderForce', ${ }^{36}$ that the underlying structure of all these reforms centres on a combination of liberal, radical and cultural feminist mechanisms that are unable to address feminist critiques of the structural inequalities that inform understandings of military and legal mechanisms within Western liberal democracies.

\footnotetext{
${ }^{33}$ Michael A. Morin, 'Department of Defense Institutional Responses to increase engagement in Mental Health services among active-duty men' (2017) 18 Psychology of Men and Masculinities 251; Ronald J. Glasser, 'A War of Disabilities: Iraq's Hidden Costs are Coming Home' (July 2005) Harper's 59.

${ }^{34}$ UN Security Council, Security Council resolution 1960 (2010) [on women and peace and security], 16 December 2010, S/RES/1960(2010),

${ }^{35}$ See PeaceWomen, United Nations Office, National Action Plan: United Kingdom, January 2018, available online at: http://www.peacewomen.org/nap-uk (last accessed January 2018).

${ }^{36}$ Earlier initiatives to develop the GenderForce seem to have subsequently been abandoned. For an early discussion see Charlotte Isaksson, 'GenderForce: why didn't we do this before?' Open Democracy, (online) 29 November 2012 https://www.opendemocracy.net/5050/charlotte-isaksson/genderforce-why-didnt-we-do-thisbefore (last accessed January 2018).
} 
The UK National Action Plan on women, peace and security includes five central agendas: increased participation of women in conflict zones; the prevention of conflict and of violence against women and girls; the protection of the human rights of women and girls; and the building of national capacity. ${ }^{37}$ Similarly, the US National Action Plan addresses: national integration and institutionalization; participation in peace processes and decision-making; protection from violence; and access to relief and recovery. ${ }^{38}$ Both are impressive documents with considerable diversity in the strategies they recommend and develop, as well as comprehensive justification for the need to centre women's contributions in conflict affected areas. The strategies deployed utilise radical, liberal and cultural feminist modes to mobilise action in conflict affected areas through a focus on participation and protection, and emphasis on women's needs and contributions as distinct from those of men. Both documents, consequently, entrench gender strategies that focus on women, rather than the gendered lives of men and women, and emphasise the experience of gender as binary and, latent within this, as predominantly heteronormative. In addition, women's diversity and diverse needs are negated other than via the distinction between women with access to elite decision-making spaces and those that are imagined to need protection. This fails to address diversity within conflict and peacetime spaces, the over-representation of elite men in decision-making spaces and reimagines Western women's lives as the marker of gender achievements/ goals. ${ }^{39}$

Both the US and the UK further invest in gender via the development of training initiatives within their militaries and through NATO. These are predominantly pre-deployment opportunities, although additional training courses are developed for training of foreign policing and military personnel in post-conflict communities. The requirement for militaries to develop gender training is elaborated in

\footnotetext{
${ }^{37}$ UK Foreign and Commonwealth Office, UK National Action Plan on women, peace and security 2014-2017, available online at: https://www.gov.uk/government/uploads/system/uploads/attachment_data/file/319870/FCO643 NAP_Printing final3.pdf (last accessed January 2018).

${ }^{38}$ Available online at: http://www.peacewomen.org/sites/default/files/us_nationalactionplan_2011.pdf (last accessed January 2018).

${ }^{39}$ See further Gina Heathcote, 'Participation, Gender and Security' in Gina Heathcote and Dianne Otto (eds) Rethinking Peacekeeping, Gender Equality and Collective Security (Palgrave, 2014) 48.
} 
the Security Council's resolutions on women, peace and security; including in resolution 2122 where the Council,

... encourages troop- and police-contributing countries to provide all military and police personnel with adequate training to carry out their responsibilities, and relevant United Nations entities to make available appropriate guidance or training modules, including in particular the United Nations predeployment scenario-based training on prevention of sexual and gender based violence. ${ }^{40}$

In the UK armed forces these provisions have been translated into predeployment training that focuses on the policy of zero tolerance of sexual exploitation and abuse, as well as training with regard to the impact of sexual violence on women (and men) in conflict and post-conflict settings. In NATO this is referred to as 'Gender Awareness Training' ${ }^{41}$ There does seem to be a gap between the description in NATO publicity and the way this materialises both in training and on missions. For example, French Army Major Nichol indicates: 'We need to take into consideration the gender perspective now, in the training, the preparation, and the doctrine. You need to be trained and need to have strong knowledge about what gender is, and how to deal with it in your daily work' as core to the NATO gender training. However, she then gives the following practical example of the impact of this approach: '[i]n a hospital setting, for example, we need to ensure there are females available to assist with female patients and males to assist with male patients' ${ }^{42}$ The distinction between gender perspectives and responding differently to men and women in the field suggests the incorporation of gender perspectives into a core aspect of training - whether predeployment as in the UK example or at commander level as in the NATO example - tends to collapse back into the emphasis on the protection of women from sexual violence and/or the use of gender to refer to women, underscoring gender difference.

\footnotetext{
${ }^{40}$ Security Council resolution $2122\left(18^{\text {th }}\right.$ October 2013) para. 9.

${ }^{41}$ See further (page 5): NATO, NATO/EAPC Action Plan for the Implementation of the NATO/EAPC Policy on Women Peace and Security, 2014, available online at: http://www.nato.int/nato_static_fl2014/assets/pdf/pdft_2016_07/160718-wps-action-plan.pdf (accessed January 2018).

${ }^{42}$ Quoted at: NATO, NATO ACT promotes Global Gender Perspective Training, 16 January 2015, available online at: http://www.act.nato.int/nato-act-promotes-global-gender-perspective-training (accessed January 2018).
} 
The all-female Indian peacekeeping contingent deployed to Liberia in January 2007 was considered a world first - although single gender peacekeeping contingents are in fact the norm, if we remember to 'see' being a man as inhabiting a gender. In addition to the establishment of all-female peacekeeping contingents, the percentage of women on UN missions has increased during the life of the women, peace and security resolutions. ${ }^{43}$ The UN describes the inclusion of women in peacekeeping operations as 'inspiring and empower[ing] women and girls' and able to 'broaden the skill set available to peacekeeping missions' ${ }^{44}$ The Security Council resolutions on women, peace and security also promote the inclusion of female peacekeepers, ${ }^{45}$ tying this to protecting women and girls and preventing sexual violence. ${ }^{46}$ Both the UK and US armed forces have also deployed FETs (Female Engagement Teams) as part of the armed forces in Iraq and Afghanistan. ${ }^{47}$ The mobilisation of FETs, however, is increasingly giving way to METs (Mixed Engagement Teams) with both the UK and US focusing on the different skills men and women bring to different roles. This is reminiscent of the argument, above, identifying women as essentially different to men, in a cultural feminist embrace of gender difference.

In sum, what these initiatives demonstrate is a preparedness of both the US and the UK, as well as their allies, to develop gender initiatives that reproduce dominant modes of Western feminist theorising, in particular those models which avoid challenging the structural dynamics of war and law. At the core of these feminist projects is a feminist subject who is female, white, liberal, able-bodied,

\footnotetext{
${ }^{43}$ This is often reported as 'doubling'. However, it is important to note that the increase is from around one per cent of UN peacekeepers to female peacekeepers constituting around three percent of total military personnel on UN missions. For further discussion, see: Paul Kirby and Laura Shepherd, 'The Futures Past of the Women, Peace and Security Agenda' (2016) 92(2) International Affairs 373 at 374.

${ }^{44} \mathrm{UN}$ poster campaign, see: http://www.un.org/en/peacekeeping/issues/women/womeninpk.shtml (last accessed January 2018).

45 SC Res 1325, para. 4; SC Res 1820, para. 8; SC Res 1888, para. 19; SC Res 1960, para. 15; SC Res 2106, para. 14; SC Res 2122, para. 9; SC Res 2242, para. 8. SC Res 1889 contains no reference. SC Res 2242 is the most extensive, welcoming efforts to incentivise increased deployment, acknowledging obstacles and setting the goal to double numbers.

46 See SC Res 1820, para. 8.

${ }^{47}$ See further, Sippi Azarbaijani Moghaddam, Seeking out their Sisters: Female Engagement Teams in Afghanistan, CMI Working Paper 2014: 1, Chr. Michelson Institute, 2014, available online at: http://www.nato.int/issues/women_nato/2014/5096-seeking-out-their-afghan-sisters.pdf (last accessed January 2018).
} 
heteronormative in her sexuality and either available for inclusion under empowerment and participation tropes or (because she is not white) a victim and in need of both legal and military protection. In addition, gender initiatives, such as the creation of FETs, produce a narrative of women as essentially different to men in a manner that seems dangerously close to biological essentialist claims surrounding gender and sex difference. This dislodges and diminishes the lives of many women's lives from feminist projects while simultaneously ignoring and disenfranchising the many, multiple feminist projects that engage a complex understanding of subjectivity.

\subsection{Male soldiers - the maimed male body as product of war (meet Tammy Duckworth)}

Alongside the attention to women as gendered subjects of law, replicated in gendered understandings of technologies and the technologies of gender perspectives, the predominance of men as military subjects has received scant academic attention within the gender and conflict literature. ${ }^{48}$ When men, as specifically gendered subjects, in conflict have been incorporated at the institutional level this has been to address the issue of male victims of conflict-related sexual violence. ${ }^{49}$ In this section, I analyse the impact of injury and harm on returned soldiers and on armed forces. I examine the role of technologies and of gender equality through the experience of US congresswomen and returned soldier, Tammy Duckworth. ${ }^{50}$ I contrast Duckworth's use of assistive technologies (and their availability to her as a member of the US armed forces) with the work and writing of Mexican artist Frida Kahlo, whose exoskeleton/ body cast/ brace and exoskeleton creations (such as the image

\footnotetext{
${ }^{48}$ For important starting points, see: PR Higate 'Peacekeepers, Masculinities and Sexual Exploitation' (2007) 10 (1) Men and Masculinities 99; D. Zarkov, 'The Body of the Other Man' in Caroline O. N. Moser and Fiona C. Clark (eds) Victims, Perpetrators or Actors? (Zed Books 2001) 69; Carol Cohn, 'Slick 'Ems, Glick 'Ems, Christmas Trees, and Cutters: Nuclear Language and how we learned to pat the bomb' (1987) 43(5) Bulletin of the Atomic Scientists 17; Sandesh Sivakumaran, 'Sexual Violence against Men in Armed Conflict' (2007) 18 (2) European Journal of International Law 253; Paul Kirby and Marsha Henry, 'Rethinking Masculinity in Conflict and Postconflict Settings' (2012) 14(4) International Feminist Journal of Politics 445.

${ }^{49}$ See, for example United Nations Office for the Co-ordination of Humanitarian Affairs, 'Discussion Paper 2 : The Nature, Scope and Motivation for Sexual Violence against Men and Boys in Armed Conflict' paper presented for discussion at the UN OCHA Research Meeting on the Use of Sexual Violence in Armed Conflict: Identifying Gaps in Research to Inform more Effective Interventions, $26^{\text {th }}$ June 2008.

${ }^{50}$ See further Tammy Duckworth, Meet Tammy (2018) available online at: http://tammyduckworth.com/meettammy/ (last accessed January 2018).
} 
below) adorn her house evoking new subjectivities drawn from the connection between debility and creativity. ${ }^{51}$

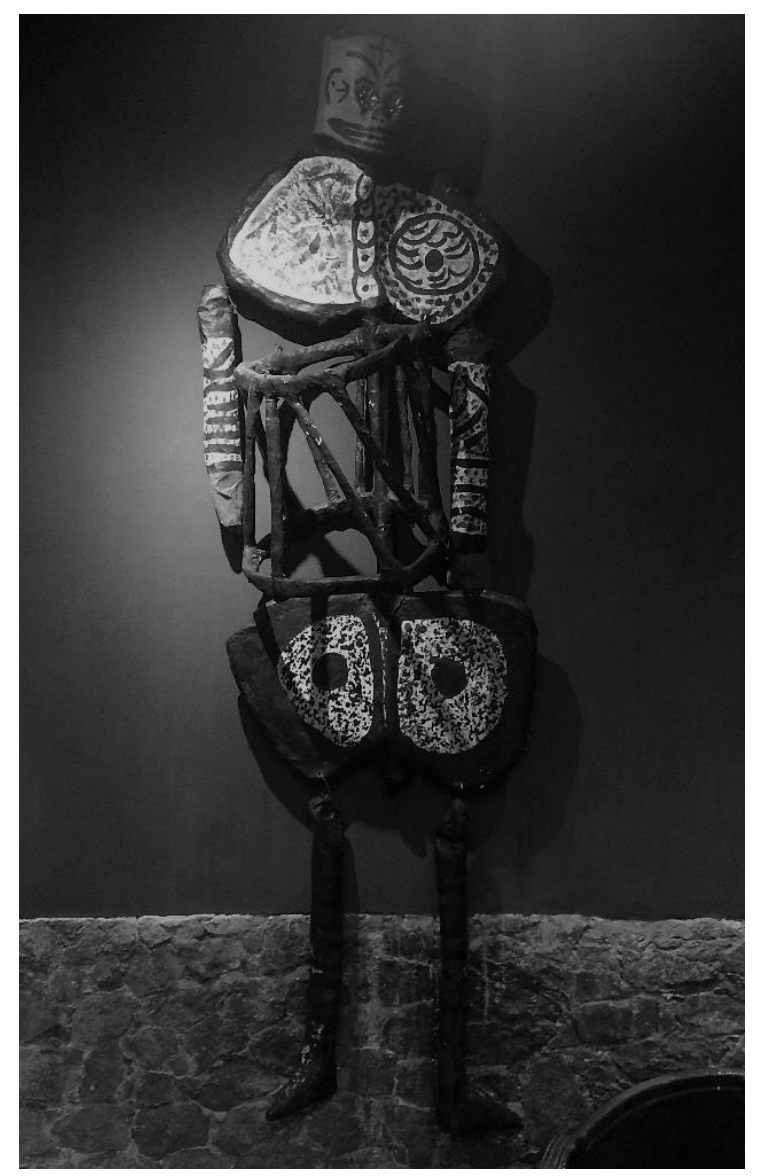

Figure Two: Exoskeleton at Casa Azul

Information about the extent of injury experienced by US and UK military on the battlefield is

difficult to ascertain. The UK charity 'Help for Heroes' ${ }^{52}$ commissioned a study in 2014 that

established between 1991 and 2014 approximately 66000 returned soldiers would be eligible for the types of assistance the charity offers, described as 'to help those wounded in the conflicts in Iraq and Afghanistan' ${ }^{53}$ In the US, there are an estimated 44000 paralysed veterans - with the overall post-

\footnotetext{
${ }^{51}$ With thanks to Safet HadziMuhamedovic who suggested incorporating Kahlo's work into the discussion, for information on Safet's work see: http://www.bosnianlandscapes.com/ (last accessed January 2018).

${ }^{52}$ See http://www.helpforheroes.org.uk/ (last accessed January 2018).

${ }^{53}$ See Help for Heroes, How Many People need the support of Help for Heroes, available online at: http://www.helpforheroes.org.uk/about/our-faqs/(last accessed January 2018); however, this assistance does not extend to assistance for Afghan and Iraqi citizens injured by armed conflict, see further Erevelles, above note 22.
} 
conflict injury and health complications obviously much higher. ${ }^{54}$ Government assistance programmes in the US and UK range from support for mental health and substance abuse, to pensions and rehabilitation from injury, although these are supplemented by charitable organisations that undertake similar roles in veteran communities. In the US, and in parallel to the development of exoskeletons for the use on the battlefield, approval has been given for ReWalk Robotics' US $\$ 77000$ exoskeleton to be paid for by the US Veterans' Affairs for eligible paralysed veterans. ${ }^{55}$ Pilot studies of the benefits of ReWalk technologies indicate "paraplegics who used the exoskeleton as little as four hours a week for three to five months experienced better bowel and bladder function, reduced back pain, improved sleep and less fatigue' ${ }^{56}$ The accessibility of (and funding of research to support) advanced assistive technologies for returned service-men and -women in the US underscores the resilience of the understanding of soldiers as arch-citizens: having sacrificed themselves for the nation-state and thus justifying access to medical and mobility resources otherwise out of reach for those with similar mobility restraints not caused by serving in the US armed forces. The dual investment of the US in exoskeletons as elite advantage on the battlefield and as state of the art medical enhancement for returned soldiers provides a curious image of desire to inflict suffering and to repair suffering within the same technology.

One beneficiary of assistive technologies, although prosthetics rather than an exoskeleton, in the US is Senator Tammy Duckworth. Elected to the US House of Representatives on 2012, Duckworth is a former helicopter pilot in the US army and was injured when the helicopter she was in command of was shot down in Iraq in 2003. Duckworth lost both of her legs due to the explosion but was subsequently fitted with state-of-the-art prosthetics. As both a woman and a person of colour,

\footnotetext{
${ }^{54}$ Julie Watson, 'VA Sets National Policy for Robotics Legs for Paralysed Vets', AP News, December $18^{\text {th }}$ 2015, available online at: https://apnews.com/aa96a84cf66747ae9d9e4ee1825ed920/apnewsbreak-va-providerobotic-legs-paralyzed-vets (last accessed January 2018).

${ }^{55}$ Michael Hoffman, 'Exoskeletons Show Promise for Veterans, Special Operators' Tandem NSI, February $3^{\text {rd }}$ 2016, available online at: http://www.tandemnsi.com/2016/02/exoskeletons-show-promise-for-veterans-specialoperators/ (last accessed January 2018).

${ }^{56}$ Julie Watson, 'VA Sets National Policy for Robotics Legs for Paralysed Vets', AP News, December $18^{\text {th }}$ 2015, available online at: https://apnews.com/aa96a84cf66747ae9d9e4ee1825ed920/apnewsbreak-va-providerobotic-legs-paralyzed-vets (last accessed January 2018).
} 
Duckworth's rehabilitation and appointment to the House of Representatives present a striking example of both hypervisible debility (rendered ability through technology?) and advanced assistive technology, that is typically available to US veterans. This combination of 'superhuman' and former veteran significantly underscores her credibility as a political candidate in a manner not always afforded to women and people of colour in Western liberal democracies. ${ }^{57} \mathrm{In}$ the following section I return to the complexities of the construction of race and gender in understandings of citizenship, and the role military service can play in embedding citizenship within communities that are often discriminated against.

At this point I wish to contrast the representation of Duckworth as more-than capable citizen, established in some ways through her background as a servicewoman and the sacrifice to the State through the injuries she has endured. This might be contrasted with Frida Kahlo's use of her comparatively primitive - exoskeletons that form both the plaster and leather braces Kahlo was forced to wear throughout her life and that provide stimulus for the design and creation of art, such as in Figure Two. Kahlo's use of exoskeletons, and the braces she wore, as stimulus for her art interlock with many of her images that fuse body and (medical) technologies, animals, emotions and landscape in fascinating and beguiling ways. While Kahlo's work presents her body as clumsy outcast it also, always, draws the viewer into her complex relationships with others, with the environment and, often, with animals. The injuries that Kahlo lives with both render her unique and also provide the space of connection and empathy, such that her creative works are widely celebrated in a manner rare for a female artist from the Global South.

As such, while Tammy Duckworth's resilience and achievements are nothing short of admirable, her military background does place her story as a reproduction of the productivity of war: for the state and the individual. In contrast, Kahlo's work asks of us to centre and simply accept debility as part of the

\footnotetext{
${ }^{57}$ See, for example, Julie Dumbo, 'Experience: I was given New Hands for Christmas', The Guardian, 5 January 2018, available online at: https://www.theguardian.com/lifeandstyle/2018/jan/05/experience-i-wasgiven-new-hands-for-christmas (last accessed January 2018).
} 
wider motifs of subjectivity which she employs: connecting matter, non-humans and technologies. This contrast between the need to affirm citizenship via rehabilitation and the role of soldiering as a marker of citizenship, that has the potential to erase gendered and racial difference, is the focus of my discussion in the following section.

\subsection{Vulnerabilities in war and peace - debility and legal subjectivities}

... between fixing and forgetting ...[s]uccessful rehabilitation permitted the "formerly" disabled body to be reintegrated into the nation's significant social structures, such as work and family. Made "ordinary" again, "identical" to "normal" citizens, the disabled would “disappear". ${ }^{58}$

James' account of the relationship between the disabled body, black bodies in the US and soldier/citizenship draws out the complicated structural history of solider/citizens in the US. She argues for recognition of the history of blackness in the US to be understood as 'synonymous with disability' as 'black men have envisaged military participation as an avenue toward liberation and citizenship, heeding the call for "able-bodied" men needed to fill military ranks. . ${ }^{59}$ Through an analysis of the literary texts of Gwendolyn Brooks, James argues for the need for representation, rather than repression, of the injured and maimed Black body returned from war. As such, James demonstrates the relationship between legal subjectivity, citizenship and soldiering in the US. In arguing that military service might 'undo' the othering of the black male body in the US, James in effect acknowledges the white, masculine subject of law who need not act to gain full subjectivity.

However, James also challenges the accuracy of “"ableist's" representations' for 'the act of representation, no matter how "authentic," aids in this estrangement precisely because the disabled are mediated ${ }^{9}{ }^{60}$ The military mindset to repair and restore the returned soldier through assistive technologies likewise re-produces the expectation that the maimed body is not-quite a full subject and

\footnotetext{
58 James above note 30 at 138 .

59 As above at 142 .

${ }^{60}$ As above at 150.
} 
that the restoring of the body is necessary to be a full citizen. This approach, argues James, ignores the constructed nature of the debility produced through warfare and thus reifies the notion that the body must always be restored from debility. Drawing on the work of Stiker,${ }^{61}$ James writes:

This cosmetic fix allows the inequalities created by political, social and ideological practices that relegate certain bodies to economic, gender, sex and physical (racial) alterity to conveniently recede from view . . . through "naturalizing" socially produced disability, naming all difference "disability" and claiming all "disabled" capable of "rehabilitation," preventative measures are judged unnecessary. ${ }^{62}$

James' argument recognises, then, not only the socially constructed nature of disability resultant from armed conflict, but also the social construction of 'the poor to the unemployed' as Other and in need of rehabilitative interventions by the state, rather than recognition of any need to transform structural inequalities. However, James' approach also highlights the 'socially constructed' nature of disability which, I argue might have two meanings. ${ }^{63}$ First, as James writes, drawing on Stiker, a host of differences become marked as 'disabled' in a manner that requires individual interventions over structural change. Second, thinking through the disabled body returning from combat, the body is twice constructed as damaged, initially through the risk contained in a political decision to send armed forces to combat situations which is, in essence, a constructed risk and then through the need to "restore" the body of the soldier, rather than care or accept differences associated with disability. For individuals who are thus framed as disabled, whether as the consequence of political decisions, political apathy or from chronic, genetic or other medical conditions, the focus remains on the rehabilitation to become able-bodied rather than a recognition that all bodies carry debilities, risk debility and are debilitated. Likewise, there is a failure to see how compulsory ablebodiedness is

\footnotetext{
${ }^{61}$ Henri-Jacques Stiker, A History of Disability (University of Michigan Press 1999).

${ }^{62}$ James, above note 18, at 141, quoting Striker, above note 25, pp. 174-175.

${ }^{63}$ There is a large oeuvre of important scholarship on this point. See, in particular Michael Oliver, 'Illness and Disability: Conflicting Definitions of Chronic Illness, Impairment and Disability' in Elizabeth E. Emens and Michael Ashley Stein (eds) Disability and Equality Law (Routledge 2013) 3 (on the social model of disability); Tom Shakespeare, Disability Rights and Wrongs Revisited (Routledge 2013) (promoting a 'critically realist approach'); Kay Inckle 'A Lame Argument: Profoundly Disabled Embodiment as Critical Gender Politics' (2014) 29 Disability and Society 388 (on the need to see and recognise the lived experiences of 'disabled embodiment' that are often lost in social models of disability); also see Erevelles above note 23.
} 
attributed to the imagined subject of law. The shift to honouring, accepting, seeing debility as integral to subjectivity thus frames subjectivity differently and, potentially, accepts the interface of technology with any body as an aspect of subjectivity just as the entwined relationships with humanness and matter, environment and non-human animals have the potential to radically alter legal constructions and engagements with subjectivity.

James goes on to remind us that the dismembered female form has a long history in Western iconography from the Venus de Milo to the cropped female body of contemporary Hollywood films: 'if women are reduced to "parts", black women are split even further as they are asked to pry the signs of blackness from their bodies and as blackness is ripped from their bodies and reshaped into a myriad of cultural signifiers' ${ }^{64}$ The maimed body of war must therefore be restored in a way that female and black bodies can never be restored/ completed, re-inscribing white masculine histories into the project of assistive military technologies for returned soldiers. For Gunaratnam, 'Race and gender, in other words, complicate the cultural presence of disability'. ${ }^{65}$ Thinking forward, through these re-readings of the material and discursive effects of subject formation, borne through the experience of citizenship and its various dislocations, and invisibly carried through legal categorisation, demands new modes of understanding and representing subjectivity.

An alternative framing of subjectivity might thus begin with the notion of debility and the body, acknowledging thus the interrelated othering of racial and gendered Others in the construction of legal subjectivity endured by modern man. Debility thus frames the future interface with technology as not rehabilitative, or restorative, rather akin to the already-interface between technology and humans: a process that has a history as old as human invention. The technology of fire, for example,

\footnotetext{
${ }^{64}$ James, above note 30 at 155.

${ }^{65}$ Yasmin Gunaratnam, 'A Space Nerd Explores Her Inner Cosmos in 'Crumb-sized' Poems: On Marlena Chertock's new collection of "sci-poetry"' (Review of Marlena Chertock, Crumb-sized: Poems, Unnamed Press, 2017) Chicago Review of Books, January 2018, available online at: https://chireviewofbooks.com/2017/08/15/crumb-sized-poems-marlena-chertock-review/ (last accessed January 2018).
} 
fundamentally altered human existence, changed her needs, patterns and consumptions. Moreover, the contemporary use of technology has starkly changed the understanding of humanness, how humans live, interact, survive. At the same time both technology and humans impact on the livelihoods of non-human animals and of earth. To shift toward the notion of intertwined existence - or subjectivities - the exoskeleton has inspired me to see the human body as body-never-whole-nevercomplete and as ordinary in its dependencies on others, including non-human animals, matter and technologies. Thus, drawing on Reeves, it is necessary to recognise:

For people with impairments, the hybridisation of machine/human or animal/human is often synonymous with lived experience, particularly for those with physical or sensory impairments ... Potential cyborg figures can be seen in the wheelchair user, the person with a cochlear implant, artificial leg or pacemaker, someone who uses an assistance dog. ${ }^{66}$

While Reeve acknowledges the differential cultural readings of different technologies, their gendered meanings, the economic privileges required for access, the dependencies and the increased means of medical surveillance technologies invoked must also be heeded. Reeve argues, '[r]ather than seeing technology as 'fixing' impaired people in normative ways (and therefore to be rejected), it is more productive to see the new ways of being in the world that emerge from living as cyborg' ${ }^{67}$ Thus to see the debilitated body ${ }^{68}$ as motif for reimagining subjectivity requires recognition of the ways the conceptualisation of modernist man has always rendered the non-male, nonheterosexual/heteronormative body as not only othered but debilitated. Feminist theorising on subjectivity and feminist legal projects might thus take the othered body as the conceptual lens to engage the non-human, matter and technology. Viva la Frida!

\footnotetext{
${ }^{66}$ Donna Reeve, 'Cyborgs, Cripples and iCrip: Reflections on the Contribution of Haraway to Disability Studies' in Dan Goodley, Bill Hughes and Lennard Davis (eds) Disability and Social Theory (Palgrave 2012) 94.

${ }^{67}$ As above at 107.

${ }^{68}$ Reeve, as above, uses the term 'impaired'; I prefer the term debilitated - and invoke this with a sense that all bodies are debilitated and have the potential for debility; however, see Inckle, above note 21, who rejects the term, drawn from Puar's work, debility. Also see Erevelles, above note 23, who writes, 'How can acquiring a disability be celebrated as "the most universal of human conditions" if it is acquired under the oppressive conditions of poverty, economic exploitation, police brutality, neo-colonial violence and lack of access to adequate health care and education?' at 119.
} 


\section{After Exoskeletons of Equality}

This article started as a sense of dissatisfaction with the idea that exoskeletons might positively contribute to gender equality. My dissatisfaction is driven by a combination of seeing a misunderstanding as to what gender equality would, in fact, entail and a renewed sense of the utter futility of armed conflict as a solution to, well, anything. In probing further into the relationship between battlefield technologies my mind continually rested on two further points of discussion, one conceptual, one material, that I had an instinct needed to be spoken about together. First, there seemed to be a need to remember that when writing, speaking, listening, thinking about gender equality the discussion never rests with who has access to what or who is represented in law but extends to the political and philosophical understanding of subjectivity within law - that is, who is understood to be the subject of law and provides the template for 'humanness' in our engagements. Given the topic is about the interface of human and non-human technologies, a rejection of modernist accounts - born of Enlightenment preoccupation with the white, economically privileged man as subject and all the exclusions that entails - becomes my preoccupation. Second, this underlying conceptualisation of subjectivity, if challenged from a feminist perspective, requires a recognition of the bodies that subjectivity shapes, mains, empowers, notices and inscribes within law. To gender the bodies under discussion, and render bodies ever-present, requires a feminist attention (to the opposite of technology as bodily enhancement) to see the bodies damaged and distorted by war, which are, for Western militaries, overwhelmingly male. Contemporary gender equality moves within the US and UK armed forces offer the opportunity to increase the count of non-male bodies to be repaired and restored by assistive technologies. These words bring me a great deal of dissatisfaction and anxiety.

Why do men send other men to war to come home damaged, in body and in mind? Why do men accept other men choosing war and how can gender equality rest on preparing women to meet men on the battlefield? It strikes me that this age-old gender equality trope is going to meet some familiar hurdles - about women (feminists?) being peaceful and women having the right to be the same as men - that I have chosen not to revisit in this paper. Instead, the question (or the answer, you choose) can 
be distilled so as to ask each of us serious questions about who she/he is that we imagine at the base of political, legal and philosophical projects. Can she be a cyborg, ${ }^{69}$ part machine? Can she be body and mind, animal, machine and non-human? Can she imagine her role within a dynamic of interspecies relationships, human and non-human networks and dependencies, perhaps with gender no longer the visible, invisible determinate of how, who, when, what?

While I write the sun shines through the glass onto my limbs, its presence (warmth and light) significantly changes me, and my experience of my body, and changes the environment around me so much that when the sun is not felt, particularly as warmth, I crave her return. This dependency is central to me. This dependency interacts with other non-human elements both within and without me. My limbs stretch into the space of light. What would happen, I wonder, if those limbs were wires? What subject arrives enmeshed with wires, flesh and non-human matter? Can she matter?

${ }^{69}$ See, for extended discussion, Reeve above note 66. 